\title{
Gaya Kepemimpinan Demokratis dan Pemberian Insentif untuk Meningkatkan Motivasi Pegawai pada Kantor SETDA Kabupaten Jepara
}

\section{Sugeng Sutrisno}

Fakultas Ekonomika Dan Bisnis Untag Semarang sugengsutrisno1967@gmail.com

\section{Suparmi}

Fakultas Ekonomika Dan Bisnis Untag Semarang suparmi.untag@yahoo.com

\section{Sukardi}

Fakultas Ekonomika Dan Bisnis Untag Semarang sukardipkl@yahoo.com

\begin{abstract}
Abstrak
Democratic reformation, to ward employer more clean responsible, pofessional to make efissien and effective birocratic, to create prime to the people. Purpose of this research is how to know The Effect of Democratic Leadership Style and Incentives on Motivation in the Regional Secretariat Office of Jepara Regency. Then this research is done by quantitative method with multiple linear regression analysis. Insentive is the most influential variable on motivation. So if the insentive carried out properly by employees, it can mean the motivation of employees also increased. The result of t test also shows that there is positive and significant influence between insentive on employee motivation of Regional Secretariat of Jepara Regency. If the Democratic Leadership Style of the employees is done well, then the motivation of the employees is also getting better. The t test results also show there is a positive and significant influence between Democratic Leadership Style on employee motivation in Regional Secretariat of Jepara Regency
\end{abstract}

Kata Kunci Democratic Leadership Style, Insentive and Motivation

I.

PENDAHULUAN

Good Governance merupakan issue yang paling mengemuka dalam pengelolaan administrasi publik dewasa ini. Tuntutan gencar dilakukan oleh masyarakat kepada pemerintah agar terselenggara pemerintahan yang baik sejalan dengan meningkatnya pengetahuan masyarakat serta adanya pengaruh globalisasi menuntut adanya keterbukaan. Pola- pola lama penyelenggaraan pemerintah tidak sesuai lagi bagi tatanan masyarakat yang telah berubah. Terlebih setelah diberlakukannya Undang- undang Nomor 22 tahun 19 tentang Pemerintahan Daerah yang telah direvisi menjadi Undang- undang Nomor 32 tahun 2004.

Reformasi birokrasi diarahkan untuk menciptakan aparatur yang bersih, bertanggung jawab, profesional, birokrasi yang efisien dan efektif, dan menciptakan pelayanan prima kepada masyarakat. Secara konseptual dalam menciptakan hal tersebut dimulai dari redefinisi visi, misi dan strategi, kajian restrukturisasi pemisahan dan 
penggabungan serta penajaman fungsi, kajian analisis beban kerja unit-unit organisasi. SDM aparatur sebagai penggerak dan penyelenggara tugastugas pemerintahan memegang peranan penting dalam suatu sistem pemerintahan. Oleh karenanya, pondasi dasar reformasi birokrasi seutuhnya harus dimulai dari reformasi terhadap pengelolaan/ manajemen SDM aparaturnya. Reformasi pengelolaan SDM aparatur ini merupakan kebutuhan mendesak untuk dijalankan agar diperoleh aparatur yang professional, berkinerja tinggi, dan sejahtera dalam menyokong pencapaian pengelolaan birokrasi yang baik.

Pegawai Negeri Sipil (PNS) adalah pegawai yang telah memenuhi syarat yang ditentukan, diangkat oleh pejabat yang berwenang dan diserahi tugas dalam suatu jabatan negeri, atau diserahi tugas negara lainnya, dan digaji berdasarkan peraturan perundangundangan yang berlaku. Setiap pegawai negeri memiliki hak dan kewajiban yang sudah diatur dalam perundang-undangan. Kewajiban PNS diatur dalam pasal 3 PP 53 Tahun 2010 tentang disiplin pegawai Pegawai Negeri Sipil. Sedangkan Hak PNS adalah sebagai berikut: 1. Gaji; (a. Gaji PNS; b. Perhitungan masa kerja; c. Kenaikan gaji pokok; d. Tunjangan), 2. Kenaikan Pangkat; 3. Daftar Penilaian Pelaksanaan Pekerjaan; 4. Cuti; 5. Tunjangan cacat dan uang duka; 6. Kesejahteraan; 7. Pensiun. 8. Mendapatkan pendidikan dan Pelatihan.

Banyaknya hak yang diperoleh PNS, sehingga seharusnya PNS lebih termotivasi untuk bekerja. Motivasi terbentuk dari sikap pegawai dalam menghadapi situasi kerjadi tempat kerja baik itu dinas atau instansi pemerintah maupun perusahaan. Motivasi merupakan kondisi atau energi yang menggerakkan diri/ pegawai yang terarah untuk mencapai tujuan organisasi maupun pegawai itu sendiri. Sikap mental pegawai yang pro dan positif terhadap situasi kerja itulah yang memperkuat motivasi kerjanya untuk mencapai kinerja maksimal.

Robbins (2011) mengemukakan bahwa motivasi sebagai suatu kerelaan untuk berusaha seoptimal mungkin dalam pencapaian tujuan organisasi yang dipengaruhi oleh kemampuan usaha untuk memuaskan beberapa kebutuhan individu. Penelitian Musdalifah (2016) menyatakan insentif mempunyai pengaruh positif signifikan terhadap motivasi pegawai. Penelitian Rizky (2012) juga menyatakan kepemimpinan, insentif dan disiplin secara berpengaruh positif dan signifikan terhadap motivasi pegawai.

Salah satu instansi yang memiliki motivasi beragam pada PNSnya adalah kantor SETDA Jepara. Kantor SETDA Kabupaten Jepara adalah salah satu instansi pemerintah yang mempunyai fungsi dalam bidang pengelolaan dan pengendalian tata usaha dan administrasi kepegawaian, perencanaan dan pengelolaan keuangan serta urusan rumah tangga perangkat daerah. Untuk menyelenggarakan fungsi sebagaimana dimaksud, SETDA mempunyai tugas di antaranya menyusun rencana kegiatan SETDA, melaksanakan pelayanan administrasi kepegawaian, melaksanakan pengelolaan surat menyurat, kearsipan dan administrasi umum, melaksanakan pelayanan administratif dan fungsional Sekretariat Daerah, melaksanakan pengendalian dan pembinaan dan penatausahaan perjalanan dinas di lingkungan Sekretariat Daerah, melaksanakan pengendalian dan pelaksanaan norma, standar, pedoman, dan petunjuk operasional di bidang umum, melaksanakan monitoring, evaluasi, dan pelaporan kegiatan SETDA dan melaksanakan tugas lain yang di berikan Asisten Administrasi Umum sesuai dengan lingkup tugas dan fungsinya.

Upaya dalam menciptakan motivasi yang tinggi di kantor ini belum optimal dikarenakan terdapat beberapa kendala-kendala yang dihadapi. Kendala-kendala tersebut seperti absensi pegawai dimana masih terdapat pegawai yang datang terlambat dan pulang lebih awal dan bahkan waktu jam kerja sering tidak kelihatan ditempat kerja, pimpinan kurang memberi masukan - masukan yang positif kepada pegawai, pimpinan kurang memberikan semangat kepada pegawai, tidak adanya kompensasi kepada pegawai, 
pimpinan kurang menghargai pendapat/ masukan yang di berikan pegawai kepada atasan, pimpinan kurang mencontohkan sikap disiplin. Oleh sebab itu pemimpin harus mampu mengelola Sumber Daya Manusia dan setiap pemimpin mempunyai metode memimpin dalam mencapai tujuan organisasi. Rivai dan Mulyadi (2011), menyatakan bahwa kepemimpinan secara luas meliputi proses mempengaruhi dalam menentukan tujuan organisasi, memotivasi perilaku pengikut untuk mencapai tujuan, mempengaruhi interprestasi mengenai peristiwa-peristiwa para pengikutnya, pengorganisasian dan aktivitas- aktivitas untuk mencapai sasaran, memelihara hubungan kerja sama dan kerja kelompok, perolehan dukungan dan kerja sama dari orang-orang di luar kelompok atau organisasi.

Menurut Kartono (2013) Menyatakan sebagai berikut: Gaya kepemimpinan adalah sifat, kebiasaan, tempramen, watak dan kepribadian yang membedakan seorang pemimpin dalam berinteraksi dengan orang lain. Menurut Thoha (2010) mengemukakan bahwa: Gaya kepemimpinan merupakan norma prilaku yang digunakan oleh seseorang pada saat orang tersebut mencoba mempengaruhi prilaku orang lain atau bawahan. Menurut Herujito (2012) menyatakan gaya kepemimpinan demokratis adalah sebagai berikut: Gaya kepemimpinan demokratis bukan bakat, oleh karena itu gaya kepemimpinan demokratis dipelajari dan dipraktekan dalam penerapannya harus sesuai dengan situasi yang dihadapi. Sedangkan menurut Supardo (2012), menyatakan bahwa: Gaya kepemimpinan demokratis adalah suatu cara dan porses kompleks dimana seseorang mempengaruhi orang-orang lain untuk mencapai suatu misi, tugas atau suatu sasaran dan mengarahkan organisasi dengan cara yang lebih masuk akal.

Hasil penelitian Alhudhori dkk (2019) menyatakan kepemimpinan berpengaruh positif dan signifikan terhadap motivasi. Bukhori dkk (2019) juga menyatakan kepemimpinan berpengaruh positif dan signifikan terhadap motivasi. Hasil penelitian Sambiran (2019) juga menyatakan Kepemimpinan berpengaruh secara positif dan signifikan terhadap motivasi kerja. Semakin baik kepemimpinan, maka motivasi kerja akan meningkat. Sesuai dengan kepemimpinan mempunyai pengaruh positif dan signifikan terhadap motivasi kerja.

Hasil penelitian Prasastono (2012) terdapat pengaruh positif dan signifikan antara gaya kepeminpinan terhadap motivasi kerja. Hasil penelitian Wida (2017) juga menyatakan kepemimpinan berpengaruh secara positif dan signifikan terhadap motivasi kerja. semakin baik kepemimpinan, maka motivasi kerja akan meningkat. sesuai dengan kepemimpinan mempunyai pengaruh positif dan signifikan terhadap motivasi kerja.

Selain kepemimpinan, insentif juga sangat berpengaruh terhadap motivasi. Pembayaran insentif yang diberikan kepada karyawan dilakukan atas dasar kinerja yang melebihi standar yang telah ditetapkan pemerintah. Saat ini di Pemerintahan Jepara diberlakukan insentif bagi yang satu bulan full tanpa absen dan terlambat, hal ini akan meningkatkan motivasi dan semangat kerja pegawai. Tujuan dari pemberian insentif ini adalah suatu bentuk perusahaan memperlakukan karyawannya sebagai asset yang perlu diberi penghargaan serta menjadikan karyawan tersebut sebagai mitra usaha sehingga karyawan mempunyai rasa memiliki terhadap perusahaan tersebut. Dengan demikian cukup berasalan bagi perusahaan untuk membayar karyawan tersebut dengan insentif sesuai dengan hasil kerjanya. Menurut Handoko (2012), menyatakan bahwa pengertian insentif adalah Perangsang yang ditawarkan kepada para karyawan untuk melaksanakan kerja sesuai atau lebih tinggi dari standar-standar yang telah ditetapkan.

Hasil penelitian Alhudhori dkk (2019) menyatakan insentif berpengaruh positif dan signifikan terhadap motivasi. Bukhori dkk (2019) juga menyatakan insentif berpengaruh positif dan signifikan terhadap motivasi. Hasil penelitian Sambiran (2019) juga menyatakan insentif berpengaruh secara positif dan signifikan terhadap motivasi kerja. 
Semakin baik kepemimpinan, maka motivasi kerja akan meningkat. Sesuai dengan insentif mempunyai pengaruh positif dan signifikan terhadap motivasi kerja.

Berikut ini merupakan hasil prasurvey di SETDA Kabupaten Jepara yang menggambarkan motivasi para pegawainya.

Tabel 1. Hasil Pra Survey Pegawai Pada Kantor SETDA Kabupaten Jepara Tahun 2019

\begin{tabular}{|l|l|c|c|c|c|c|}
\hline No & \multicolumn{1}{|c|}{ Pertanyaan } & Ya & $(\%)$ & Tidak & $(\%)$ & Total \\
\hline 1. & $\begin{array}{l}\text { Pegawai SETDA selalu mengikuti apel } \\
\text { pagi maupun apel siang }\end{array}$ & 23 & 76.67 & 7 & 23.33 & 100 \\
\hline 2. & $\begin{array}{l}\text { Pegawai SETDA masih ada yang } \\
\text { meninggalkan kantor pada saat jam } \\
\text { kerja }\end{array}$ & 11 & 36.67 & 19 & 63.33 & 100 \\
\hline 3. & $\begin{array}{l}\text { Pimpinan memberikan contoh yang } \\
\text { baik pada bawahannya }\end{array}$ & 18 & 60.00 & 12 & 40.00 & 100 \\
\hline 4. & $\begin{array}{l}\text { Pegawai SETDA rutin membuat LKH } \\
\text { laporan kerja harian) }\end{array}$ & 20 & 66.67 & 10 & 33.33 & 100 \\
\hline 5. & $\begin{array}{l}\text { Pegawai SETDA selalu mengikuti } \\
\text { upacara hari -hari besar nasional }\end{array}$ & 19 & 63.33 & 11 & 36.67 & 100 \\
\hline
\end{tabular}

Sumber: Pra Survey Di SETDA Jepara.

Hasil pra survey yang di lakukan pada 30 orang staf pegawai pada kantor SETDA kabupaten Jepara, dengan melihat hasil dari pra survey terdapat ciri - ciri apa saja yang dapat menyebabkan motivasi kerja belum berjalan maksimal. Hal yang demikian terlihat pada jawaban responden, dimana perbandingan jawaban ya dan tidak pada setiap pertanyaan. Perbandingan tersebut sangat di dominasi pada jawaban ya dan tidak yang di ajukan pada pegawai SETDA Kabupaten Jepara, dengan demikian dapat di nyatakan naik turunnya motivasi pegawai. Dalam mencapai tujuan organisasi peran seluruh pegawai dan kepemimpinan sangat berpengaruh dalam meningkatkan motivasi kerja, dalam hal ini pentingnya koordinasi yang baik di antara bidang setiap jabatan di dalam setiap menjalan aktivitasnya. Kondisi pegawai dalam SETDA Kabupaten Jepara perlu ditingkatkan insentifnya sehingga pelaksanaan tugas dan pelayanan masyarakat.

Permasalahan yang dihadapi oleh SETDA Jepara adalah masalah pengelolaan pengembangan sumber daya manusia khususnya dalam peningkatan motivasi kerja, di mana motivasi kerja merupakan hal yang sangat penting untuk mendorong karyawan dalam meningkatkan kemampuan dibidangnya, oleh karena itu untuk dapat mempengaruhi para karyawannya diperlukan suatu gaya kepemimpinan demokratis, di mana gaya kepemimpinan yang dimiliki seorang pemimpin SETDA berbeda-beda. Kepemimpinan (Leadership) merupakan proses mengarahkan dan mempengaruhi aktivitas yang berkaitan dengan pekerjaan dari para ASN. Kepemimpinan demokratis adalah proses mempengaruhi dalam menentukan tujuan organisasi, memotivasi perilaku pengikutnya untuk mencapai tujuan dan mempengaruhi kelompok dan budayanya secara demokratis.

Selain gaya kepemimpinan dmokratis faktor lain yang dapat memotivasi seorang karyawan supaya kinerjanya meningkat yaitu pemberian insentif, dimana insentif sebagai sarana motivasi yang mendorong para pegawai untuk bekerja dengan kemampuan yang optimal, yang dimaksudkan sebagai pendapatan ekstra di luar gaji yang telah ditentukan. Pemberian insentif dimaksudkan agar dapat memenuhi kebutuhan para pegawai dan keluarga mereka.Insentif merupakan suatu faktor pendorong bagi pegawai untuk bekerja lebih baik agar motivasi pegawai dapat meningkat.Di SETDA Jepara ini insentif yang diberikan berupa finansial dan nonfinansial. Rata - rata ASN yang diberikan insentif 
terutama finansial adalah tambahan penghasilan atau Tamsil, yakni bila ASN tidak pernah telat dan selalu bekerja sesuai aturan yang berlaku.

Berdasarkan latar belakang yang terjadi pada SETDA Kabupaten Jepara di temukan permasalahan yang perlu untuk di teliti yaitu Gaya Kepemimpinan Demokratis dan Pemberian Insentif Untuk Meningkatkan Motivasi Pegawai pada Kantor SETDA Kabupaten Jepara.

\section{LANDASAN TEORI}

\section{Gaya Kepemimpinan Demokratis}

Menurut Thoha ( 2013 ), Gaya Kepemimpinan merupakan pola perilaku karakteristik pemmpin saat mengarahkan, memotivasi, membimbng dan mengelola sekelompok orang dengan tujuan menginspirasi gerakan demi perubahan.

Sementara itu, Gaya Kepemimpinan Demokratis merupakan pemimpin yang mempunyai gaya kepemimpnan dimana pemimpin suatu organisasi maupun kelompok menerima pendapat atau saran dari setiap anggotanya untuk menentukan suatu keputusan bersama dalam organisasi demi mencapai tujuan.

Menurut GR Thery (2006), Gaya Kepemimpinan Demokratis merupakan pemimpin yang mempunyai gaya kepemimpnan dimana pemimpin suatu organisasi maupun kelompok menerima pendapat atau saran dari setiap anggotanya untuk menentukan suatu keputusan bersama dalam organisasi demi mencapai tujuan dan menganggap dirinya sebagai bagian yang tidak tepisahkan.

Menurut Hasibuan (2006), Gaya Kepemimpinan Demokratis adalah cara seorang pemimpin mempengaruhi perilaku bawahan agar mau bekerja sama dan bekerja secara efektif dan efisien untuk mencapai tujuan.

Dari beberapa pengertian diatas dapat disimpulkan bahwa Gaya Kepemimpinan Demokratis merupakan pemimpin yang mempunyai gaya kepemimpnan dimana pemimpin suatu organisasi maupun kelompok menerima pendapat atau saran dari setiap anggotanya untuk menentukan suatu keputusan bersama dalam organisasi demi mencapai tujuan dan mengaggap dirinya sebagai bagian yang tidak tepisahkan.

\section{INSENTIF}

Menurut Rochmateral (2013), Insenf adalah sistem pemberian jasa yang dikaitkan dengan kinerja baik bersifat material maupun non material yang dapat memberikan motivasi atau daya pendorong bagi karyawan untuk bekerja lebih baik dan bersemangat sehingga kinerja karyawan lebih meningkat yang pada akhirya tuuan dapat tercapai.

Menurut Nafrizal (2012), Isentif merupakan rangsangan yang dberkan kepada karyawan dengan tujuan mendorrong karyawan dalam bertindak dan berbuat sesuatu untuk mencapai tujuan..

Menurut Rivai (2009), Insentif adalah bentuk pembayaran yang dkaika dengan kinerja dan gaisharing sebagai pembagian keuntungan bagi karyawan akibat penngkatan produkifitas atau penhematan biaya.

Dari beberapa pengertian diatas dapat disimpulkan bahwa insentif adalah bentuk rangsangan yang sengaja diberikan oleh institusi kepada karyawan agar termivasi an mau bekerja dengan sungguh sungguh sehingga tujuan dapat tercapai.

\section{MOTIVASI}

Menurut Edwin B Flippo (2005), Motivasi adalah suau keahlian dalam mengarahkan pegawai dan organisasi agar mau bekerja secara berhasil sehingga para pegawai dapat mencapai tujuannya. 
Menurut T Hani Handoko (2005), Motivasi adalah keadaan pribadi seseorang yang mendorong keingnan individu untuk melakukan kegiatan tertentu guna mencapai tujunan.

Menurut Henry Simamora (2005), Motivasi adalah sebuah fungsi dari pengharapan individu bahwa upaya tertentu akan menghasilkan tingkat kinerja yang pada gilirannya akan membuahkan imbalan atau hasil yang dikehendaki.

\section{III.METODE PENELITIAN}

\section{Populasi dan Sampel}

Populasi yaitu jumlah dari keseluruhan obyek-obyek (satuan - satuan atau individu-individu) (Arikunto, 2013). Populasi dalam penelitian ini adalah semua Pegawai Negeri Sipil SETDA Kabupaten Jepara dengan jumlah 99 orang.

Sampel merupakan himpunan atau subset dari populasi, terdiri dari beberapa anggota populasi (Ferdinand, 2012). Pengambilan sampel pada penelitian ini menggunakan metode survey atau sensus yaitu cara pengambilan seluruh populasi menjadi sampel (Suharsimi, 2012)

\section{Metode Pengumpulan Data}

Metode pengumpulan dalam penelitian ini menggunakan kuesioner. Kuesioner adalah teknik pengumpulan data yang dilakukan dengan cara memberikan seperangkat pertanyaan atau pernyataan tertulis kepada responden untuk dijawab, di mana peneliti tidak langsung bertanya jawab dengan responden (Echdar, 2017:299).

Dalam penelitian ini, kuesioner dibuat dengan menggunakan Skala Likert yaitu skala untuk mengukur sikap, pendapat, dan persepsi seseorang atau sekelompok orang tentang fenomena sosial (Echdar, 2017:298).

\section{Prosedur Pengumpulan Data}

Prosedur pengumpulan data yang digunakan dalam penelitian ini adalah:

\section{a. Data Primer}

Data primer adalah sumber data yang dikumpulkan secara langsung dari sumber asli (tidak melalui media perantara) dengan kuesioner melalui pengumpulan data yang di lakukan dengan memberikan pertanyaan-pertanyaan kepada responden dengan panduan kuesioner.

\section{b. Data Sekunder}

Data sekunder adalah data penilaian yang diperoleh peneliti secara tidak langsung melalui media perantara (diperoleh dan dicatat oleh pihak lain). Data sekunder dalam penelitian ini yang akan diambil antara lain meliputi identitas

\section{Pengujian Instrumen Validitas}

Berdasarkan hasil uji validitas dapat diketahui bahwa semua indikator variabel gaya kepemimpinan demokratis, pemberian insentif dan motivasi dinyatakan valid, karena dari korelasi antara hasil jawaban responden pada setiap item pertanyaan dengan skor total diperoleh hasil yang signifikan, yaitu nilai sig. lebih kecil (<) 0,05.

\section{Reliabilitas}

Tabel 2. Hasil Uji Reliabilitas

\begin{tabular}{|l|c|c|}
\hline \multicolumn{1}{|c|}{ Variabel } & $\begin{array}{c}\text { Cronbach's } \\
\text { Alpha }\end{array}$ & Keterangan \\
\hline $\begin{array}{l}\text { Gaya Kepemimpinan } \\
\text { Demokratis }\end{array}$ & $0,822>0,70$ & Reliabel \\
\hline
\end{tabular}




\begin{tabular}{|l|c|l|}
\hline Pemberian Insentif & $0,851>0,70$ & Reliabel \\
\hline Motivasi & $0,724>0,70$ & Reliabel \\
\hline
\end{tabular}

Nilai cronbach's alpha masing-masing variabel lebih besar dari 0,70. Dengan hasil ini maka kuesioner yang digunakan oleh variabel gaya kepemimpinan demokratis, nsentif dan motivasi dinyatakan reliabel.

\section{Analisis Hasil Penelitan}

Analisis Regresi Berganda

Tabel 3. Hasil Regresi Berganda

\begin{tabular}{|c|c|c|c|c|c|}
\hline \multirow[t]{2}{*}{ Model } & \multicolumn{2}{|c|}{$\begin{array}{c}\text { Unstandardized } \\
\text { Coefficients }\end{array}$} & $\begin{array}{l}\text { Standardized } \\
\text { Coefficients } \\
\end{array}$ & \multirow[t]{2}{*}{$\mathrm{t}$} & \multirow[t]{2}{*}{ Sig. } \\
\hline & B & Std. Error & Beta & & \\
\hline (Constant) & ,397 & ,696 & & $\overline{5}, 570$ & ,571 \\
\hline $\begin{array}{l}\text { Gaya } \\
\text { Kepemimpina } \\
\text { n Demokratis }\end{array}$ & ,359 & ,072 & ,479, & 4,966 & ,000 \\
\hline $\begin{array}{l}\text { Pemberian } \\
\text { Insentif }\end{array}$ & 239, & ,051 & ,453 & 4,692 & ,000 \\
\hline
\end{tabular}

a. Konstanta $(\alpha)=0,397$. Nilai positif yang didapat menunjukkan apabila gaya kepemimpinan demokratisdan pemberian insentif dalam keadaan tetap maka motivasi positif.

b. Gaya Kepemimpinan Demokratis $\left(\beta_{1}\right)=0,359$. Nilai positif yang didapat menunjukkan adanya peningkatan gaya kepemimpinan demokratis akan meningkatkan motivasi

c. Pemberian Insentif $\left(\beta_{2}\right)=0,239$. Nilai positif yang didapat menunjukkan adanya peningkatan pemberian Insentif akan meningkatkan motivasi.

\section{Uji Normalitas}

Tabel 4. Hasil Uji Normalitas

One-Sample Kolmogorov-Smirnov Test

\begin{tabular}{|ll|r|r|r|}
\hline & & $\begin{array}{c}\text { Gaya } \\
\text { Kepemimpina } \\
\text { n Demokratis }\end{array}$ & $\begin{array}{c}\text { Pemberian } \\
\text { Insentif }\end{array}$ & Motivasi \\
\hline $\mathrm{N}$ & & 65 & 65 & 65 \\
Normal Parameters & Mean & 13,78 & 20,66 & 10,29 \\
& Std. Deviation & 2,875 & 4,082 & 2,156 \\
Most Extreme & Absolute &, 147 &, 148 &, 125 \\
Differences & Positive &, 147 &, 119 &, 125 \\
Kolmogorov-Smirnov Z & Negative &,- 100 &,- 148 &,- 121 \\
Asymp. Sig. (2-tailed) & 1,186 & 1,197 & 1,009 \\
\hline
\end{tabular}

Nilai sig. kolmogorov smirnov test variabel gaya kepemimpinan demokratis sebesar 0,120, pemberian insentif sebesar 0,114, dan motivasi sebesar 0,260. Nilai sig. yang didapat di atas 0,05 sehingga dapat disimpulkan bahwa data dari masing - masing variabel berdistribusi normal

\section{Uji Asumsi Klasik}




\section{Uji Heteroskedastisitas}

Tabel 5. Hasil Uji Heteroskedastisitas

Coefficients $^{\mathrm{a}}$

\begin{tabular}{|c|c|c|c|c|c|c|}
\hline \multirow[t]{2}{*}{ Mod } & & \multicolumn{2}{|c|}{ Unstandardized Coefficients } & \multirow{2}{*}{$\begin{array}{c}\text { Standardized } \\
\text { Coefficients }\end{array}$} & \multirow[t]{2}{*}{$\mathrm{t}$} & \multirow[t]{2}{*}{ Sig. } \\
\hline & & B & Std. Error & & & \\
\hline \multirow{6}{*}{1} & (Constant) & ,876 & 403 & & 2,175 & ,033 \\
\hline & Gaya & & & & & \\
\hline & Kepemim & & (017 & 200 & 1501 & \\
\hline & Demokrati & , &, 042 & , 290 & $1, J 01$ & ס \\
\hline & & & & & & \\
\hline & $\begin{array}{l}\text { Pemberian } \\
\text { Insentif }\end{array}$ &,- 045 & ,029 &,- 300 & $-1,509$ & ,136 \\
\hline
\end{tabular}

Hasil uji heteroskedastisitas memperlihatkan bahwa nilai sig. gaya kepemimpinan demokratis sebesar 0,138 dan pemberian motivasi sebesar 0,136. Nilai sig. masing-masing variabel lebih besar (>) dari 0,05 sehingga pada model regresi berganda tidak terjadi heteroskedastisitas.

\section{Uji Multikolinearitas}

Tabel 7. Hasil Uji Multikolineritas

\begin{tabular}{|c|c|c|c|}
\hline \multirow[t]{2}{*}{ Model } & & \multicolumn{2}{|c|}{ Collinearity Statistics } \\
\hline & & Tolerance & VIF \\
\hline \multirow{4}{*}{1} & (Constant) & & \\
\hline & Gaya & & \\
\hline & Kepemimpina & ,393 & 2,545 \\
\hline & $\begin{array}{l}\text { Pemberian } \\
\text { Motivasi }\end{array}$ & 393 & 2,545 \\
\hline
\end{tabular}

Hasil nilai Tolerance masing-masing variabel independen di atas 0,1 , sementara nilai VIF di bawah 10, dengan demikian antara variabel independen gaya kepemimpinan demokratis dan pemberian insentif tidak terjadi multikolinearitas

\section{Koefisien Determinasi}

Tabel 8. Hasil Koefisien Determinasi Model Summary ${ }^{b}$

\begin{tabular}{|l|r|r|r|r|}
\hline Model & R & R Square & $\begin{array}{c}\text { Adjusted R } \\
\text { Square }\end{array}$ & $\begin{array}{c}\text { Std. Error of } \\
\text { the Estimate }\end{array}$ \\
\hline 1 &, $879^{\mathrm{a}}$ &, 773 &, 766 & 1,043 \\
\hline
\end{tabular}

Besarnya koefisien determinasi dapat dilihat pada Adjusted $R$ Square sebesar 0,766. Hal ini dapat diartikan bahwa gaya kepemimpinan demokratis dan pemberian insentif mampu menjelaskan motivasi sebesar 76,6\% (0,766 x 100\%) sementara sebesar $23,4 \%(100 \%$ - 76,6\%) motivasi ditentukan variabel di luar model. 


\begin{tabular}{|rl|r|r|r|r|r|}
\hline \multicolumn{1}{|l|}{ Model } & \multicolumn{1}{|c|}{ Sum of } & df & Mean Square & F & Sig. \\
& Squares & & & & \\
\hline \multirow{2}{*}{1} & Regression & 229,952 & 2 & 114,976 & 105,616 &, $000^{\mathrm{b}}$ \\
& Residual & 67,495 & 62 & 1,089 & & \\
& Total & 297,446 & 64 & & & \\
\hline
\end{tabular}

Hasil uji - F sebesar 105,616 dengan sig. 0,000 lebih kecil (<) 0,05. Hasil ini menunjukkan bahwa model regresi gaya kepemimpinan demokratis dan pemberian motivasi terhadap motivasi sudah baik atau fit.

\section{Pengujian Hipotesis}

Tabel 10. Hasil Uji - t
\begin{tabular}{|l|r|r|}
\hline Model & \multicolumn{1}{c|}{ t } & \multicolumn{1}{c|}{ Sig. } \\
\hline (Constant) &, 570 &, 571 \\
\hline $\begin{array}{l}\text { Gaya Kepemimpinan } \\
\text { Demokratis }\end{array}$ & 4,966 &, 000 \\
\hline Pemberian Insentif & 4,692 &, 000 \\
\hline
\end{tabular}

Berdasarkan dari hasil uji - $\mathrm{t}$ dapat dilakukan pembuktian sebagai berikut:

1. Hasil uji - t gaya kepemimpinan demokratis terhadap motivasi sebesar 4,966 dengan sig. 0,000 lebih kecil dari 0,05 sehingga menerima hipotesis yang menyatakan gaya kepemimpinan demokratis berpengaruh positif dan signifikan terhadap motivasi.

2. Hasil uji - t pemberian insentif terhadap motivasi sebesar 4,692 dengan sig. 0,000 lebih kecil dari 0,05 sehingga menerima hipotesis yang menyatakan pemberian insentif berpengaruh positif dan signifikan terhadap motivasi

\section{HASIL DAN PEMBAHASAN}

\section{Pengaruh Gaya Kepemimpinan Demokratis Terhadap Motivasi}

Gaya kepemimpinan demokratis menurut Thoha (2013) dikaitkan dengan kekuatan personal dan keikutsertaan para pengikut dalam proses pemecahan masalah dan pengambilan keputusan. Kepemimpinan yang ditetapkan oleh seorang pimpianan dalam organisasi dapat menciptakan integrasi yang serasi dan mendorong gairah kerja pegawai untuk mencapai sasaran yang maksimal. Kepemimpinan merupakan hal yang sangat penting dalam manajerial, karena kepemimpinan maka proses manajemen akan berjalan dengan baik dan pegawai akan bergairah dalam melakukan tugasnya.

Berdasarkan hasil koefisien regresi menunjukkan bahwa apabila didalam organisasi Kantor Setda Kabupaten Jepara gaya kepemimpinan demokratis telah dijalankan dengan baik, maka bisa diartikan motivasi para pegawai juga semakin meningkat. Hasil uji t juga menunjukkan ada pengaruh positif dan signifikan antara kepemimpinan terhadap motivasi pegawai di Sekretariat Daerah Kabupaten Jepara. 
Hasil penelitian ini sama dengan penelitian Sundoro Yekti (2012) yang menyatakan gaya kepemimpinan memiliki pengaruh positif terhadap motivasi pegawai. Sementara penelitian Irma Satya Indriyanti (2015) menyatakan Gaya Kepemimpinan berpengaruh negatif Terhadap motivasi. Akan tetapi penelitian Rommy dan Jantje (2016) menyatakan kepemimpinan berpengaruh positif dan signifikan terhadap motivasi pegawai. Dan penelitian Helen Sepmon Firstie1 Dan Siti Madin (2017) menyatakan gaya kepemimpinan demokratis memiliki pengaruh yang positif signifikan Terhadap motivasi

\section{Pengaruh Pemberian Insentif Terhadap Motivasi}

Menurut Handoko (2012), menyatakan bahwa pengertian insentif adalah Perangsang yang ditawarkan kepada para karyawan untuk melaksanakan kerja sesuai atau lebih tinggi dari standar-standar yang telah ditetapkan.

Berdasarkan hasil koefisien regresi menunjukkan bahwa apabila insentif diberikan kepada pegawai Kantor Setda Kabupaten Jepara dengan layak, maka motivasi para pegawai juga semakin meningkat. Hasil uji t juga menunjukkan ada pengaruh positif dan signifikan antara insentif terhadap motivasi pegawai di Sekretariat Daerah Kabupaten Jepara.

Hasil penelitian ini sama dengan penelitian Alhudhori dkk (2019) yang menyatakan insentif berpengaruh positif dan signifikan terhadap motivasi. Bukhori dkk (2019) juga menyatakan insentif berpengaruh positif dan signifikan terhadap motivasi. Hasil penelitian Sambiran (2019) juga menyatakan insentif berpengaruh secara positif dan signifikan terhadap Motivasi Kerja. Semakin baik kepemimpinan, maka Motivasi Kerja akan meningkat. Sesuai dengan insentif mempunyai pengaruh positif dan signifikan terhadap Motivasi Kerja.

\section{KESIMPULAN}

Berdasarkan hasil-hasil yang diperoleh dari analisis data dan keterangan dari bab-bab sebelumnya, maka dapat ditarik kesimpulan bahwa apabila gaya kepemimpinan demokratis dilaksanakan dengan baik, maka motivasi para pegawai juga semakin baik. Hasil uji t juga menunjukkan ada pengaruh positif dan signifikan antara gaya kepemimpinan demokratis terhadap motivasi pegawai di Sekretariat Daerah Kabupaten Jepara. Insentif sudah diberikan secara layak, sehingga motivasi para pegawai juga semakin meningkat. Hasil uji t juga menunjukkan ada pengaruh positif dan signifikan antara insentif terhadap motivasi pegawai di Sekretariat Daerah Kabupaten Jepara.

\section{UCAPAN TERIMA KASIH}

Penelitian dengan judul Gaya Kepemimpinan Demokratis Dan Pemberian Intensif Untuk meningkatkan Motivasi Pegawai Pada Kantor Setda Kabupaten Jepara diharapkan dapat memberikan sumbangsih dalam rangka peningkatan kinerja secara optimal dengan melihat variabel gaya kepemimpinan demokratis dan pemberian intensif merupakan faktor yang tidak bisa dikesampingkan.

Diharapkan kedepan institusi khususnya Instansi Pemerintah dapat menginisiasi untuk selalu mengedepankan cara cara yang terbaik untuk pencapaian good governance khususnya dibidang pengelolaan administrasi publik.

Kami selaku penulis tidak lupa mengucapkan banyak terima kasih kepada pihak pihak yang telah membantu pelaksanaan penelitian ini sehingga dapat terselesaikan dan tersajikan.

\section{DAFTAR PUSTAKA}

AA. Anwar Prabu Mangkunegara. 2011. Evaluasi kinerja sumber daya menusia. Bandung : PT. Rosda Karya. 
Amstrong, 2013, The art of HRD: Strategic Human Resource Management a Guide to Action Manajemen Sumber Daya Manusia Strategik Panduan Praktis Untuk Bertindak.Terjemahan Ati Cahayani. Jakarta: PT Gramedia

Ardana, I Komang, Ni Wayan Mujiati dan I Wayan Mudiartha Utama, 2012, Manajemen Sumber Daya Manusia, Edisi Pertama. Yogyakarta: Graha Ilmu.

Arikunto, Suharsimi, 2012, Prosedur Penelitian (Suatu Pendekatan Praktik), edisi Revisi VI. Jakarta: PT Rineka Cipta.

Bangun, Wilson, 2012, Manajemen Sumber Daya Manusia. Bandung: Erlangga.

Beach, L. R. 1993. Making the Right Decision Organizational Culture, Vision and Planin. New Jersey: Prentice Hall Inc.

Brando Sambiran, Jantje Sepang dan Lucky O.H Dotulong, 2015, Pengaruh kepemimpinan dan insentif finansial terhadap motivasi kerja karyawan pada PT. Adira Finance Manado. Jurnal EMBA Vol.3 No.3 Sept. 2015, Hal.1050-1058.

Daryanto, A. 2012. "Merit System Dalam Manajemen Pegawai Negeri Sipil". Jurnal Kebijakan dan Manajemen PNS. Pusat Pengkajian dan Penelitian Kepegawaian BKN

Davis, Keith dan John W. Newstrom. 2015. Perilaku Dalam Organisasi. Jakarta: Erlangga.

Dharma, Surya. 2015. Manajemen Kinerja Falsafah Teori dan Penerapannya. Jakarta: Pustaka Pelajar.

Ferdinand A. 2012. Structural Equation Modelling Dalam Peneltian Manajemen. Edisi 2. Semarang: Seri Pustaka Kunci 03/BP UNDIP.

Gibson, James L., John M. Ivancevich dan James H. Donnelly, Jr, 2012, Organisasi, Perilaku, Struktur dan Proses. Jakarta: Bina Rupa Aksara.

Gibson, James L., John M. Ivancevich, James H. Donnelly, Jr., and Robert Konopaske. 2013. Organizations: Behavior, Structure, Process (Eleventh Edition). Boston: McGraw-Hill Irwin.

Handoko, T. Hani. 2008. Manajemen Personalia Sumber Daya Manusia, Edisi Kedua. Yogjakarta: BPFE

Harlie, M. 2012. "Pengaruh Disiplin Kerja Motivasi dan Pengembangan Karier terhadap Motivasi Pegawai Negeri Sipil pada Pemerintah Kabupaten Tabalong di Tanjung Kalimantan Selatan”. Jurnal Aplikasi Manajemen, Vol. 10, No. 4, Desember 2012.

Hasibuan, Malayu S.P, 2010, Manajemen Sumber Daya Manusia, Cetakan Kedelapan. Jakarta: PT. Bumi Aksara.

Hasibuan, Malayu S.P, 2011. Manajemen Sumber Daya Manusia, Edisi Revisi, Cetakan Ketiga. Jakarta: Bumi Aksara.

Hasibuan, Malayu S.P, 2012. Manajemen Sumber Daya Manusia, Cetakan Keenam Belas. Jakarta: Bumi Aksara.

House R.J. 2012. A Theory Of Charismatic Leadership. In Leadership: The Cutting Edge (Hunt J.G. \& Larson L.L. eds). Carbondale, IL, USA: Southern Illinois University Press.

Ivancevich, John M, Konopaske Robert \& Matteson Michael T. 2012. Perilaku dan Manajemen Organisasi (Alih Bahasa Gina Gania), Edisi Tujuh. Jakarta: Erlangga.

Kartono, Kartini, 2010. Pemimpin dan Kepemimpinan. Jakarta: PT. Raja Grafindo Persada.

Kartono, Kartini, 2013, Pemimpin dan Kepemimpinan. Jakarta: Raja Grafindo Persada

Lateiner, A.R, 2014. Teknik Memimpin Pegawai dan Pekerja. Terjemahan Imam Soedjono. Jakarta:Aksara Baru..

M. Alhudhori, Evi Adriani, M. Zahari MS, Albetris, 2019, Pengaruh Gaya kepemimpinan demokratis dan Insentif terhadap Motivasi Serta Dampaknya terhadap Motivasi Pegawai Dinas Peternakan dan Perikanan Kabupaten Bungo, Ekonomis: Journal of Economics and Business, 3(2), September 2019, pp.177-185.

Malhotra, Naresg K. 2015. Riset Bisnis. Jakarta: PT. INDEKS Kelompok Gramedia 
Mangkunegara, A. Anwar Prabu, 2011. Sumber Daya Manusia Perusahaan. Bandung: Remaja Rosdakarya.

Mangkunegara, A. Anwar Prabu, 2012, Manajemen Sumber Daya Manusia, Perusahaan. Bandung: Remaja Rosdakarya.

Mangkunegara, A. Anwar Prabu, 2014. Manajemen Sumber Daya Manusia. Bandung: Remaja Rosdakarya.

Maslow, Abraham H. 2013. Motivasi dan Kepribadian. Bandung: Remaja Rosdakarya

Miner, John B dan George A. Steiner, 2013, Kebijakan Dan Strategi Manajemen, Edis Kedua. Jakarta: Erlangga.

Muhammad Bukhori, 2016, Pengaruh Gaya kepemimpinan demokratis Dan Insentif Terhadap Motivasi Kerja Serta Kinerja Karyawan Pada PT. Reza Perkasa Sidoarjo, Jurnal JIBEKA Volume 10 Nomor 1 Februari 2016:34 - 41

Nasution, 2015, Didaktik Asas-Asas Mengajar. Jakarta: Bina Aksara

Ndaru Prasastono, 2012, Pengaruh gaya kepemimpinan demokratis dan kompensasi terhadap motivasi kerja karyawan Hotel Muria Semarang, Dinamika Kepariwisataan Vol. XI No. 2, Oktober 2012.

Ordway Tead, 2015, The Art Leadership. New York: MC. Graw-Hill.

Prawirosentono, S, 2010. Jelang Perdagangan Bebas Dunia. Jakarta: BPFE

Rivai Veithzal dan Ella Jauvani Sagala. 2014. Manajemen Sumber Daya Manusia untuk Perusahaan Edisi Kedua. Jakarta: Raja Grafindo Persada.

Rivai, Veithzal, 2014, Manajemen Sumber Daya Manusia Untuk Perusahaan. Jakarta: Rajagrafindo Persada.

Rivai, Veithzal, 2015, Manajemen Sumber Daya Manusia untuk Perusahaan. Jakarta: PT. Raja Grafindo Persada.

Robbins, Stephen P dan Timoty A. Judge, 2013, Organizational Behavior, Thirteenth Edition. New Jersey: Pearson Prentice-Hal Inc. 